\title{
Possibilities of using a cyanacryl adhesive for fixation of a net implant in the laparoscopic treatment of animal herbs
}

\author{
V.P.Akimov ${ }^{1,2}$, D. Yu. Krikunov ${ }^{1}$, V. V. Toidze ${ }^{1}$, \\ M.Z.Churgulia ${ }^{1}$, V.A.Kashchenko ${ }^{3}$ \\ ${ }^{1}$ North-West State Medical University named after I. I. Mechnikov, \\ 41, ul. Kirochnaya, St. Petersburg, 191015, Russian Federation \\ ${ }^{2}$ Clinical Hospital № 122 named after L. G. Sokolov FMBA of Russia, \\ 4, pr. Kultury, St. Petersburg, 194291, Russian Federation \\ ${ }^{3}$ St. Petersburg State University, 7-9, Universitetskaya nab., St. Petersburg, 199034, Russian Federation
}

For citation: Akimov V.P., Krikunov D. Yu., Toidze V. V., Churgulia M.Z., Kashchenko V.A. Possibilities of using a cyanacryl adhesive for fixation of a net implant in the laparoscopic treatment of animal herbs. Vestnik of Saint Petersburg University. Medicine, 2018, vol. 13, issue 3, pp. 282-290. https://doi. org/10.21638/11701/spbu11.2018.305

The goal of the study was to research the results of using of glue method of fixing a mesh implant during laparoscopic hernioplasty. From 2014 to 2016 in the Clinical Hospital № 122 named after L. G. Sokolova the laparoscopic hernioplasty was performed in 128 males. Group $1^{\text {st }}-66$ patients who underwent hernioplasty with fixation of the mesh implant with cyanoacrylic glue using an alternative method of delivering the adhesive composition with elimination of the abdomen defect over the implant with V-loc thread; Group $2^{\text {nd }}-62$ patients, hernioplasty was performed with fixing of the implant with titanium staples, followed by closure of the abdomen defect with titanium staples. There were carried out the complex analysis of the life quality of patients, the number of complications and the level of abdominal pain in the early postoperative period. Laparoscopic transabdominal preperitoneal hernioplasty in combination with the use of an adhesive composition to fix the reticular implant significantly improves the patient's quality of life in the postoperative contributes to early discharge from the hospital and a faster recovery of work capacity. And the use of the proposed method of glue composition delivery significantly reduces the cost of the operation and can be easily reproduced in conditions of a surgical hospital.

Keywords: a hernia, hernioplasty, surgical adhesives.

Inguinal hernia - the most common of all hernias of the abdominal wall, it occurs in up to $80 \%$ of cases [1-3]. According to statistics, inguinal hernia disease in people aged 25 to 34 years is found in 14 cases per 1, 000 people, and at the age of 55 to 64 years - up to 53 cases per 1,000 people $[4 ; 5]$. Annually in the world more than 20 million hernias operations are carried out [6]. More than 300 different methods of hernioplasty of inguinal hernias have been described in the literature. It was noted that using classical methods, relapses occur in 10-30\% of cases, and in 3-5\% using of non-exhaustion methods of hernioplasty, with laparoscopic methods of repair of primary hernias $0-0.1 \%$, and with recurrent hernias - in 3\% of cases [7-9]. In 1988 Lichtenstein proposed his original method of hernioplasty of inguinal hernias, which was the first method in which the tension of surrounding tissues was not produced [10]. With the introduction of the Liechtenstein

(c) Санкт-Петербургский государственный университет, 2018 
method, the number of complications and relapses has abruptly dropped. While conducting studies comparing tension and non-stretch methods, "on-stretch" hernioplasty has a number of obvious advantages [10; 11], but early pain syndrome and the development of postoperative complications (development of chronic pain due to inadequate fixation, ischemia and trophic tissue disorders, poor regeneration of the p/o wound) remained in this group of patients.

From the moment of its appearance, methodology of laparoscopic hernioplasty has undergone numerous changes. M. E. Arregui offered to install endoimplant to properitoneal space and fix it to the superior pubic ligament and anterior abdominal wall that was recognized as the best option under laparoscopic method and currently is widely used in USA and Europe. This method has a title «transabdominal preperitoneal hernioplasty» (TAPP) [12; 13].

According to European Union Guidelines of inguinal hernia treatment society (European Guidelines of herniologists society on the treatment of inguinal hernia in adults, M. Miserez. et al., 2014) - penetrating fixation or traumatic devices such as surgical sutures, staples and fixators, lead to the local trauma which can be accompanied by the damage of nerves and development of chronicle pain. This is described by a few authors [14-17] - the main criterion of efficiency of operative treatment became not only frequency of relapses, but also postoperative pain, acute as well as chronic. Therefore, use of sutureless fixation (glue, mesh with "adhesive tape" principle) acquires larger popularity, since risk of postoperative complications decreases significantly. Surgical adhesives include groups: biological adhesives (fibrin), synthetic and genetically modified, derived from protein, for example cyanoacrylate. However, the use of fibrin glue significantly increases the cost of the operation, which previously limited their wide application.

Goal of the work. Improvement of treatment results of the patients with inguinal hernias by the way of using of glue fixation method of mesh implant under laparoscopic hernioplasty.

\section{Materials and methods}

On the clinical base of the Department of Surgery named after N. D. Monastyrsky of North-West State Medical University named after I. I. Mechnikov in the Clinical Hospital № 122 named. L. G Sokolova, in the period from 2014 to 2016, laparoscopic hernioplasty was performed in 128 male patients, 18 (14.1\%) of whom had recurrent inguinal hernias (hernioplasty performed in other surgical hospitals) and 110 (85.9\%) patients with primary inguinal hernia (in 9 of which the hernia was bilateral, and in 10 cases the hernias were innate). All 128 (100\%) patients underwent transabdominal preperitoneal hernioplasty. The criterion for inclusion was the presence of inguinal hernia without severe concomitant somatic pathology, which is a contraindication to performing laparoscopic interventions. Patients were divided into two groups that were comparable by sex, age, body weight index, the presence of concomitant diseases. In the $1^{\text {st }}$ group (66 patients), laparoscopic hernioplasty was performed without bringing the reticular implant under the spermatic cord and fixing it with cyanoacrylic glue "B-Vraun" with the elimination of the abdomen defect over the implant with V-loc.

We have developed original methodology of delivery of glue to the preperitoneal space. It has the same effect as official method but it's less expensive. For this we use stand- 
ard intravenous induction catheter with a guide-needle and insulinic syringe where we withdraw glue from the tube. Through the additional puncture in the middle hypogastrium we introduce a catheter in the preperitoneal space along the upper edge of the installed mesh from the medial side. Instead of fibrin glue, we used cyanoacrylate that also allowed us to simplify the operation significantly and make it cheaper. Application of glue was carried out by drip infusion along the mesh transplant, therefore, it doesn't limit the use of fixation in triangles of "pain" and "fate".

The $2^{\text {nd }}$ group includes 62 males who underwent laparoscopic transabdominal preperitoneal inguinal hernia repair without cutting of mesh implant and its fixation along the periphery with titanic staples, with following closure of abdomen defect with titanic staples. In the main group an average age was $43 \pm 3$ and in the experimental group $42 \pm 3,5$. Body weight index (BWI) was from 22 to $40,7 \mathrm{~kg} / \mathrm{m}^{2}$ (table 1 ). In the $1^{\text {st }}$ group it was $29 \pm 2 \mathrm{~kg} / \mathrm{m}^{2}$ in average and in the $2^{\text {nd }}$ group $-28 \pm 3 \mathrm{~kg} / \mathrm{m}^{2}$.

Table 1 . The distribution of patient groups by body weight index, $\mathrm{kg} / \mathrm{m}^{2}$

\begin{tabular}{|c|c|c|c|}
\hline Group & Minimal & Maximal & Average \\
\hline $1^{\text {st }}, \mathrm{n}=66$ & 22,3 & 40,7 & $29 \pm 2$ \\
\hline $2^{\text {nd }}, \mathrm{n}=62$ & 22 & 39,9 & $28 \pm 3$ \\
\hline
\end{tabular}

All surgery interventions were carried out by one surgeons brigade. All hernioplasties were performed using similar mesh material. Postoperative abdominal pain was noted before the administration of analgesics, in 2, 4, 6, 12, 24, 48, 72, 96 и $120 \mathrm{~h}$ after operation. For the assessment of postoperative pain there was used visual analogue scale of bodily pain (10 scores), from "absence of pain" (0) to "insufferable pain" (10).

There was carried out an assessment of average duration of the operation and the bed-day after the operation. The quality of life of patients in a long-term postoperative period was assessed - the SF-36 questionnaire (100 points). The analysis of intro and postoperative complications in various classifications was performed. The ultrasound examination of the $\mathrm{p} / \mathrm{o}$ area on the $1^{\text {st }}, 3^{\text {rd }}$ and $7^{\text {th }}$ days after the operation was performed.

\section{Results and discussion}

The average duration of the surgical intervention is given in the table 2.

Table 2. Duration of hernioplasty, minutes

\begin{tabular}{|c|c|c|c|}
\hline Group & Minimal & Maximal & Average \\
\hline $1^{\text {st }}, \mathrm{n}=66$ & 30,5 & 129,4 & $48 \pm 2$ \\
\hline $2^{\text {nd }}, \mathrm{n}=62$ & 29,4 & 110 & $46 \pm 1,5$ \\
\hline
\end{tabular}

The longer duration of surgical intervention in the 1st group is related to the method of delivery, application of glue and suturing of the peritoneum, but the difference in average duration is practically insignificant. 
After analyzing the level of pain in the postoperative period (table 3) before the administration of analgesics, in 6 hours after the operation, we noted significant differences in the average assessment of the pain level - in the $1^{\text {st }}$ group the average score was 2 points, while in the $2^{\text {nd }}$ group -4.4 points. And after 24 hours, patients in the $1^{\text {st }}$ group did not feel any pain and were ready to leave the hospital, while in the comparison group the average pain score reached 2.9 points.

Table 3. The average assessment of the pain level from the visual analogue scale of pain intensity, scores

\begin{tabular}{|c|c|c|c|c|c|c|c|c|c|}
\hline \multirow{2}{*}{$\underset{2}{\text { Group }}$} & \multicolumn{9}{|c|}{ Time of registration the abdominal pain, hour } \\
\hline & 4 & 6 & 12 & 24 & 48 & 72 & 96 & 120 & \\
\hline $1^{\text {st }}, \mathrm{n}=66$ & 4.6 & 3.2 & 2 & 1.9 & 0.6 & 0.4 & 0.2 & 0.2 & 0.1 \\
\hline $2^{\text {nd }}, n=62$ & 7.6 & 6.5 & 4.4 & 4.4 & 2.9 & 2.9 & 2.8 & 2.9 & 1.8 \\
\hline Reliability & \multicolumn{9}{|c|}{$\mathrm{p}<0.05$} \\
\hline
\end{tabular}

We studied the early postoperative complications, which are presented in table 4 .

Table 4. Postoperative complications of laparoscopic hernioplasty, $\mathbf{n}(\%)$

\begin{tabular}{|l|l|l|l|l|}
\hline \multicolumn{1}{|c|}{ Group } & \multicolumn{1}{c|}{ Hematomas } & \multicolumn{1}{c|}{ Seromes } & \multicolumn{1}{c|}{ Neuralgia } & \multicolumn{1}{c|}{ Paresthesia } \\
\hline $1^{\text {st }}, \mathrm{n}=66$ & $1(1.51 \%)$ & $2(3.03 \%)$ & - & $1(1.51 \%)$ \\
\hline $2^{\text {nd }}, \mathrm{n}=62$ & $2(3.23 \%)$ & $4(6.45 \%)$ & $1(1.62 \%)$ & $4(6.45 \%)$ \\
\hline Reliability & $\mathrm{p}<0.05$ & & & \\
\hline
\end{tabular}

Table 5. Distribution of early postoperative complications according to Clavien Dindo classification

\begin{tabular}{|c|c|c|}
\hline Degree & $\mathbf{1}^{\text {st }}$ Group, $\mathbf{n}=66$ & $2^{\text {nd }}$ Group, $\mathbf{n}=62$ \\
\hline I & $1(25 \%)$ & $5(45.45 \%)$ \\
\hline II & - & - \\
\hline III & - & $6(54.55 \%)$ \\
\hline III a & $3(75 \%)$ & - \\
\hline III b & - & - \\
\hline IV & - & - \\
\hline IV a & - & - \\
\hline IV b & - & \\
\hline V & - & \\
\hline Reliability & $\mathrm{p}<0,05$ & - \\
\hline
\end{tabular}


Elimination of hematoma required from 1 to 3 punctures. The neuralgia developed in the region of groin and scrotum, disturbance of sensitivity and paresthesia on the front, lateral surface of a hip. These symptoms were temporary and didn't limit activity of the patients. Besides, there was carried out an analysis of early postoperative complication by the classification Clavien Dindo (table 5).

There were no relapses of hernias, no fatal cases. The average duration of stay in the hospital in the first group is 1.2 bed-day and in the second day the duration was rather higher -2.8 bed-days. Follow-up period lasted from 1 year to 2 years 11 months.

We have carried out comparative characteristics of patients' life quality after hernioplasties in the main group and experimental group (by the survey methods - questionnaire SF-36). $100 \%$ of patients took part in the survey (table 6). Among the participants, there were 128 patients of working age $(100 \%)$. Terms of caring out of the survey: 1 ) in a month after operative intervention, 2) in 3 months after operative intervention, 3 ) in 6 months and 4) in 12 month after operative intervention.

Table 6. Results of assessing the quality of life of patients in groups I, II and III according to the SF-36 questionnaire, scores

\begin{tabular}{|c|c|c|c|c|c|c|}
\hline \multirow{3}{*}{ Health Component } & \multicolumn{6}{|c|}{ Terms of observation, months } \\
\hline & \multicolumn{3}{|c|}{$1^{\text {st }}$ Group, $n=66$} & \multicolumn{3}{|c|}{$2^{\text {nd }}$ Group, $n=62$} \\
\hline & 1 & 3 & $6-12$ & 1 & 3 & $6-12$ \\
\hline \multicolumn{7}{|l|}{ Psychological } \\
\hline Vitality & $75+1.6$ & $89+1.6$ & $98+1.5$ & $67+2.1$ & $83 \pm 1.2$ & $97 \pm 2.4$ \\
\hline Social role functioning & $79 \pm 1.8$ & $89+2.7$ & $97+1.1$ & $73+1.6$ & $83+1.1$ & $96+1.3$ \\
\hline Emotional role functioning & $79 \pm 1.6$ & $93+2.1$ & $97+1.3$ & $72 \pm 1.0$ & $90+1.4$ & $95+1.4$ \\
\hline Mental health & $82 \pm 1.1$ & $91 \pm 2.9$ & $99+0.8$ & $78+1.1$ & $85 \pm 2.4$ & $97+1.3$ \\
\hline \multicolumn{7}{|l|}{ Physical } \\
\hline Physical functioning & $86+2.1$ & $92+1.6$ & $97+1.4$ & $74 \pm 1.8$ & $80 \pm 1.6$ & $96+1.8$ \\
\hline Physical role functioning & $79+2.0$ & $89+1.09$ & $97 \pm 1.3$ & $76+1.8$ & $84+1.43$ & $96+1.72$ \\
\hline Bodily pain $(\mathrm{P})$ & $81+3.06$ & $98 \pm 1.54$ & $99 \pm 0.5$ & $71+1.5$ & $88 \pm 1.6$ & $97+1.8$ \\
\hline General health perceptions & $72 \pm 1.3$ & $90+1.17$ & $98+1.3$ & $66+1.7$ & $85+1.1$ & $98 \pm 1.3$ \\
\hline Reliability & \multicolumn{6}{|l|}{$\mathrm{p}<0.05$} \\
\hline
\end{tabular}

Taking into account the data in table 6, when assessing the quality of life in the patients of the first and second group, it was revealed that when the patients were questioned in 6 months and one year after the operation, the SF-36 questionnaire did not statistically differ in quality of life. The pain sensations in the operation area (physical component) in the patients of the first group $(81 \pm 3.06)$ were 1.14 times lower in the survey 1 month after the operation than in the patients of the second group ( $71 \pm 1.5)$. And after 3 months the same (the physical component of $\mathrm{P}$ ) after the operation in the first group $(98 \pm 1,54)$, was on average 1.11 times lower than in the second. Similarly, in all other components of the 
quality of life, both in physical and psychological terms, for a period of 1 and 3 months after the surgery, the first is 1.14-1.28 times more reliable.

One of the modern approaches to the treatment of surgical pathology in general and in herniology, in particular, is not only carrying out of high technology operative interventions but also achievement of high level of rehabilitation after them. The main condition of an early rehabilitation of patients after the hernioplasty is minimization of the pain syndrome.

And as a consequence, modern trends in the treatment of inguinal hernias are aimed at improving the quality of life (reducing postoperative pain, faster recovery of work capacity and the ability to lead a habitual active lifestyle, reducing of the bed-day index). And the use of adhesive composition for fixing the mesh implants, in its turn, is ideal for observing these principles dictated by the present day, and reducing the risk of developing of chronic pain and early postoperative complications. The quality of life is one of the key concepts of modern medicine, allowing a deep multi-dimensional analysis of important components of human health in accordance with WHO criteria, that is, the physiological, psychological and social problems of a sick person.

\section{Conclusion}

The application of adhesive composition to fix the mesh implant significantly $(p<0.05)$ improves the patients' quality of life in the postoperative period: reduces pain syndrome, reduces the number of postoperative complications, and facilitates an early discharge from the hospital and a faster recovery of work capacity and the ability to lead a usual active lifestyle.

The method of delivery of the adhesive composition proposed by us makes the operation less financially expensive and cost-comparable with the classical version of laparoscopic hernioplasty using titanium staples.

The glue method of fixing the mesh implant in the treatment of inguinal hernia can be used in surgery as an alternative to other fixation methods.

The author confirms that the submitted data do not contain a conflict interests.

\section{References}

1. Strizheletsky V.V., Makarov S. A., Lomiya A. B. Opyt endovideokhirurgicheskikh tekhnologii v lechenii bol'nykh s pakhovymi gryzhami [Experience in endovideosurgical technologies in the treatment of patients with inguinal hernia]. Vestnik khirurgii im. I. I. Grekova [Bulletin of Surgery. I. I. Grekova], 2017, no. 3, pp. 74-76. (In Russian)

2. Tarasenko S. V., Zaitsev O. V., Akhmedov Sh. I. Kachestvo zhizni patsientov posle lecheniia pakhovykh gryzh metodom TARR I TER [Quality of life of patients after treatment of inguinal hernia by TAPP and TEP]. Vestnik Ross. universiteta druzhby narodov. Seriia: Meditsina [Bulletin of the Russian University of Peoples' Friendship. Series: Medicine], 2016, pp.107-110. (In Russian)

3. Tarasov S. L., Zaytsev D. V., Khalimov A.E., Kazantsev V. V. Prichiny i struktura posleoperatsionnykh oslozhnenii u bol'nykh posle allogernioplastiki [Causes and structure of postoperative complications in patients after allogernioplasty]. Gerniologiia [Gerniology], 2011, no. 1, p. 42. (In Russian)

4. Phillips A. W., Viswanath Y.K., Burns J.K., Hall C.E., Horgan A.F. Use of fibrin glue for fixation of mesh and approximation of Peritoneum in Transabdominal Preperitoneal (TAPP) inguinal hernia repair: technical feasibility and early surgical outcomes. Surg. Laparosc. Endosc. Percutan Tech., 2014, vol. 24 , no. 2 , pp. 43-45.

5. Ross S.W., Oommen B., Kim M., Walters A.L., Augenstein V.A., Heniford B.T. Tacks, staples, or suture: method of peritoneal closure in laparoscopic transabdominal pre-peritoneal inguinal hernia repair effects early quality of life. Surg Endosc., 2014. 
6. Topchiev A. M., Nurmagomedov A. G., Yusupov I. A. Rezul'taty khirurgicheskogo lecheniia bol'nykh $\mathrm{s}$ diastazom priamykh myshts zhivota $\mathrm{v}$ sochetanii s gryzhami beloi linii zhivota i pupochnymi gryzhami v zavisimosti ot sposoba operatsii i srokov predoperatsionnoi podgotovki [The results of surgical treatment of patients with diastasis of the rectus abdominal muscles in combination with hernias of the white abdominal line and umbilical hernia, depending on the method of operation and the timing of preoperative preparation]. Vestnik neotlozhnoi i vosstanovitel'noi khirurgii [Bulletin of Urgent and Reconstructive Surgery], 2016, no. 3, pp.470-477. (In Russian)

7. Akimov V.P., Levin L. A., Hurtsilava O. G., Kashchenko V.A., Kubachev K. G. Rukovodstvo po endovideokhirurgii [Manual on endovideosurgery]. St. Petersburg: Publishing house "Levsha", 2016, pp. 8194. (In Russian)

8. Lucevich O.E., Gallyamov A. E., Gordeev S. A. Laparoskopicheskaia gernioplastika: tekhnologiia budushchego [Laparoscopic hernioplasty: the technology of the future]. Zhurn. im. akad. B. V. Petrovskogo [J. of Acad. B. V. Petrovsky], 2014, no. 3, pp. 62-69. (In Russian)

9. Sazhin A. V., Klimiashvili A. D., Kochiyai E. Tekhnicheskie osobennosti i neposredstvennye rezul'taty laparoskopicheskoi transperitoneal'noi i total'noi ekstraperitoneal'noi gernioplastiki [Technical features and immediate results of laparoscopic transperitoneal and total extraperitoneal hernioplasty]. Ross. Med. Zhurn. [Russ. Med. J.], 2016, no. 3, pp. 123-129. (In Russian)

10. Bittner R., Montgomery M. A., Arregui E., Bansal V., Bingener J. Update of guidelines on laparoscopic (TAPP) and (TEP) treatment of inguinal hernia. Surg. Endosc., 2015, vol.29, no. 2, pp. 289-321.

11. Ferrarese A. Fibrin glue versus stapler fixation in laparoscopic transabdominal inguinal hernia repair: a single center 5-year experience and analysis of the results in the elderly. Int. J. Surg., 2014, vol. 12, pp. 94-98. doi: 10.1016 / j.ijsu.2014.08.371. Epub 2014.

12. Engelen M., Dilen K., Baten E. Laparoscopic treated neuralgia after inguinal hernia repair. Acta Chirurgica Belgica, 2017, no. 5, pp.283-289.

13. Niebuhr H. et al. Differentiated application of recommended guideline techniques for treatment of inguinal hernia. Der Chirurg., 2017, no. 4, pp. 276-280.

14. Abolmasov A. V. Kleevaia fiksatsiia setchatykh endoprotezov v laparoskopicheskoi khirurgii pakhovykh gryzh [Glutinous fixation of reticular endoprostheses in laparoscopic surgery of inguinal hernia]. Endoskop. khirurgiia [Endoscopic surgery], 2014, no. 1, pp.3-4. (In Russian)

15. Panyushkin A.V., Kuko M.V., Trukhalev V.A. Sravnitel'nyi analiz laparoskopicheskoi transperitoneal'noi predbriushinnoi gernioplastiki (TAPP) v lechenii pakhovykh gryzh s fiksatsiei setchatogo proteza i bez fiksatsii [Comparative analysis of laparoscopic transperitoneal periorine hernioplasty (TAPP) in the treatment of inguinal hernias with fixation of the mesh prosthesis and without fixation]. Al'm. inst. khirurg. im. A. V. Vishnevskogo [Almanac Institute of Surgery named A. V. Vishnevskogo], 2015, no. 2, pp. 936-937. (In Russian)

16. Ayyaz M., Farooka M.W., Malik A.A. Mesh fixation vs. non-fixation in total extra peritoneal mesh hernioplasty. J. Pak. Med. Assoc., 2015, no. 3, pp. 270-272.

17. Fuglestad M. A., Waisbren S. J. Two-port totally extraperitoneal inguinal hernia repair: a 10-year experience. Hernia, 2016. DOI 10.1007s10029-015-1402-5.

Author's information:

Vladimir P. Akimov — MD, Professor; akimov.spbmapo@mail.ru

Dmitriy Y. Krikunov — Postgraduate student; dmitry.krikunov.91@mail.ru

Vazha V. Toidze - $\mathrm{PhD}$

Mamuka Z. Churgulia - MD

Viktor A. Kashchenko - MD, Professor 


\title{
Использование цианакрилового клея для фиксации сетчатого импланта при лапароскопическом лечении паховых грыж
}

\author{
В. П. Акимов ${ }^{1,2}$, Д. Ю. Крикунов ${ }^{1}$, В. В. Тоидзе ${ }^{1}$, М. З. Чургулиа ${ }^{1}$, В. А., Кащенко \\ ${ }^{1}$ Северо-Западный государственный медицинский университет им. И. И. Мечникова, \\ Российская Федерация, 191015, Санкт-Петербург, ул. Кирочная, 41 \\ ${ }^{2}$ Клиническая больница № 122 им. Л. Г. Соколова ФМБА России, \\ Российская Федерация, 194291, Санкт-Петербург, пр. Культуры, 4 \\ ${ }^{3}$ Санкт-Петербургский государственный университет, \\ Российская Федерация, 199034, Санкт-Петербург, Университетская наб., 7-9
}

Для цитирования: Akimov V.P., Krikunov D. Yu., Toidze V.V., Churgulia M.Z., Kashchenko V.A. Possibilities of using a cyanacryl adhesive for fixation of a net implant in the laparoscopic treatment of animal herbs // Вестник Санкт-Петербургского университета. Медицина. 2018. Т. 13. Вып. 3. C. 282-290. https://doi.org/10.21638/11701/spbu11.2018.305

Цель исследования - изучение последствий лечения больных с паховыми грыжами с использованием клеевого метода фиксации сетчатого импланта при лапароскопической герниопластике. С 2014 по 2016 г. в клинической больнице № 122 им. Л. Г. Соколова была выполнена лапароскопическая трансабдоминальная предбрюшинная герниопластика у 128 мужчин. 66 пациентам 1-й группы операция выполнялась с фиксацией сетчатого импланта цианакриловым клеем с использованием альтернативного метода его доставки и устранением дефекта брюшины над имплантом нитью V-loc; 62 пациентам 2-й группы - с фиксацией импланта титановыми скобами, с последующим закрытием ими же дефекта брюшины. Комплексный анализ качества жизни больных, количества осложнений и уровня абдоминальной боли в раннем послеоперационном периоде показал, что применение клея для фиксации сетчатого импланта достоверно улучшает качество жизни пациента в послеоперационном периоде, способствует ранней выписке из стационара и более быстрому восстановлению трудоспособности. А использование предложенного метода доставки клеевой композиции значительно удешевляет операцию и легко воспроизводимо в условиях рядового хирургического стационара.

Ключевые слова: грыжа, лапароскопическая трансабдоминальная предбрюшинная герниопластика, клеевая методика фиксации сетчатого импланта.

\section{Литература}

1. Стрижелеикий В.В., Макаров С.А., Ломия А.Б. Опыт эндовидеохирургических технологий в лечении больных с паховыми грыжами // Вестник хирургии им. И.И.Грекова. 2017. № 3. C. 74-76.

2. Тарасенко С. В., Зайцзев О. В., Ахмедов Ш. И. Качество жизни пациентов после лечения паховых грыж методом ТАРР и ТЕР // Вестник Рос. университета дружбы народов. Серия: Медицина. 2016. C. $107-110$.

3. Тарасов С. Л., Зайцев Д. В., Халимов А. Э., Казанцев В. В. Причины и структура послеоперационных осложнений у больных после аллогерниопластики // Герниология. 2011. № 1. С. 42.

4. $\quad$ Phillips A. W., Viswanath Y.K., Burns J.K., Hall C.E., Horgan A.F. Use of fibrin glue for fixation of mesh and approximation of Peritoneum in Transabdominal Preperitoneal (TAPP) inguinal hernia repair: technical feasibility and early surgical outcomes // Surg. Laparosc. Endosc. Percutan Tech. 2014. Vol. 24, N 2. P. 43-45.

5. Ross S. W., Oommen B., Kim M., Walters A. L., Augenstein V.A., Heniford B. T. Tacks, staples, or suture: method of peritoneal closure in laparoscopic transabdominal pre-peritoneal inguinal hernia repair effects early quality of life // Surg. Endosc. 2014. 
6. Топчиев А.М., Нурмагомедов А.Г., Юсупов И.А. Результаты хирургического лечения больных с диастазом прямых мышц живота в сочетании с грыжами белой линии живота и пупочными грыжами в зависимости от способа операции и сроков предоперационной подготовки // Вестник неотложной и восстановительной хирургии. 2016. № 3. С. 470-477.

7. Акимов В. П., Левин Л. А., Хуриилава О. Г., Кащенко В. А., Кубачев К. Г. Руководство по эндовидеохирургии. СПб.: Изд-во «Левша», 2016. С. 81-94.

8. Луцевич, О. Э., Галлямов А. Э., Гордеев С. А. Лапароскопическая герниопластика: технология будущего // Журн. им. акад. Б. В. Петровского. 2014. № 3. С. 62-69.

9. Сажин А. В., Климиашвили А. Д., Кочиай Э. Технические особенности и непосредственные результаты лапароскопической трансперитонеальной и тотальной экстраперитонеальной герниопластики // Рос. мед. журн. 2016. № 3. С. 123-129.

10. Bittner R., Montgomery M.A., Arregui E., Bansal V., Bingener J. Update of guidelines on laparoscopic (TAPP) and (TEP) treatment of inguinal hernia // Surg. Endosc. 2015. T.29, N 2. P. 289-321.

11. Ferrarese A. Fibrin glue versus stapler fixation in laparoscopic transabdominal inguinal hernia repair: a single center 5-year experience and analysis of the results in the elderly // Int. J. Surg. 2014. Vol. 12. P. 94-98. doi: 10.1016 / j.ijsu.2014.08.371. Epub 2014.

12. Engelen M., Dilen K., Baten E. Laparoscopic treated neuralgia after inguinal hernia repair // Acta Chirurg. Belgica. 2017. N 5. P.283-289.

13. Niebuhr H. et al. Differentiated application of recommended guideline techniques for treatment of inguinal hernia // Der Chirurg. 2017. N 4. P.276-280.

14. Аболмасов А.В. Клеевая фиксация сетчатых эндопротезов в лапароскопической хирургии паховых грыж // Эндоскоп. хирургия. 2014. № 1. С. 3-4.

15. Панюшкин А. В., Кукош М. В., Трухалев В. А. Сравнительный анализ лапароскопической трансперитонеальной предбрюшинной герниопластики (ТАПП) в лечении паховых грыж с фиксацией сетчатого протеза и без фиксации // Альм. ин-та хирург. им. А. В. Вишневского. 2015. № 2. C. 936-937.

16. Ayyaz M., Farooka M. W., Malik A.A. Mesh fixation vs. non-fixation in total extra peritoneal mesh hernioplasty // J. Pak. Med. Assoc. 2015. N 3. P. 270-272.

17. Fuglestad M.A., Waisbren S.J. Two-port totally extraperitoneal inguinal hernia repair: a 10-year experience // Hernia. 2016. doi: 10.1007s10029-015-1402-5.

Контактная информация:

Владимир Павлович Акимов - д-р мед. наук, проф.; akimov.spbmapo@mail.ru.

Дмитрий Юрьевич Крикунов - аспирант; dmitry.krikunov.91@mail.ru.

Важа Васильевич Тоидзе - канд. мед. наук

Мамука Зурабович Чургулиа - канд. мед. наук

Виктор Анатольевич Кащенко - д-р мед. наук, проф. 